\title{
Typology of cattle farms in the northern regions of Cameroon
}

\author{
Justin Kouamo $^{1 *}$ Paul Pa-ana ${ }^{1}$
}

\section{Keywords}

Bos indicus, artificial insemination, typology, copulation, milk production, zebu, Cameroon

Submitted: 28 July 2017

Accepted: 4 January 2018

Published: 12 March 2018

DOI : $10.19182 /$ remvt. 31520

\begin{abstract}
Summary
The aim of this study was to establish the typology of cattle farms in the northern regions of Cameroon in order to reveal structural and functional characteristics that could be selected for an artificial insemination program. A survey was carried out among 54 breeders. The results showed that the farmers were predominantly of the Fulani ethnic group (81.5\%) with men prevailing (92.6\%). Their levels of education were primary $(31.5 \%)$, secondary $(18.5 \%)$, and higher $(25.9 \%)$. They were involved in full-time agricultural production activity $(42.6 \%)$, cattle breeding and agropastoralism. Civil servants represented more than a third of the sample. The genetic structure of the herds was dominated by local breeds: $53.7 \%$ Gudali zebus, $44.4 \%$ Djafoun and $5.6 \%$ Akou. In addition, $44.4 \%$ of them bred crossbreeds and $16.7 \%$ Holsteins. A multiple correspondence analysis was performed to determine the typology of the farms studied. Based on the structural (herd size, forage area, dairy productivity per cow per day, and related infrastructure) and functional (feeding, herd management, technological choice) characteristics of the farms, three types were identified. Type I breeders (37\%) practiced the extensive system, and type II breeders (18.5\%) the semi-intensive system. They were present in the Adamawa region and preferred natural mating (56\%) and artificial insemination $(100 \%)$, respectively, as a reproductive means. Type III breeders $(44.5 \%)$ practiced the semi-extensive system. They were only present in the North and Far North regions and preferred (98\%) natural mating as a reproductive means. Type II farmers were located in Vina Division (Adamawa) and they offered the best potentialities with the practice of artificial insemination. They may be considered as pilot for the revival of the dairy sector in this part of Cameroon.
\end{abstract}

- How to quote this article: Kouamo J., Pa-ana P., 2017. Typology of cattle farms in the northern regions of Cameroon. Rev. Elev. Med. Vet. Pays Trop., 70 (3): 73-80, doi: 10.19182/remvt.31520

\section{INTRODUCTION}

In Cameroon, $35 \%$ of the rural population lives exclusively on livestock (MINEPIA, 2013). Thus, livestock is the sector that offers the largest number of opportunities to rural populations in the northern regions, both in the diversity of the types of livestock and in the multiplicity of activities that are developing in this sector such as fattening, milk production, dairy processing (ACDIC, 2006). Ensuring food security in milk and dairy products is a priority for public authorities implementing intensification strategies based on the production of local cattle breeds. With an estimated population of 5.8 million head of cattle (MINEPIA, 2015) and the natural conditions favorable to livestock in certain regions, the high demand for milk and milk products constitutes a potential opportunity. Milk production is carried out essentially in a traditional way. The modern part barely represents $2 \%$ of production. The milk sector, although having significant potential, remains

\footnotetext{
1. School of Veterinary Medicine and Sciences, University of Ngaoundere, PO Box 454, Ngaoundere, Cameroon.

* Corresponding author

Tel.: +237675 3769 54; Email: justinkouamo@yahoo.fr
}

undeveloped. Total milk production is currently estimated at 174,000 tons over an average lactation period of about 180 days. Total consumption of milk and dairy products was around 260,000 tons in 2015 and will reach 310,000 tons in 2025 . The consumption per inhabitant per year of 19.8 kilograms is much lower than the world average of 45 kilograms (MINEPIA, 2015). Thus, an intensive breeding program using artificial insemination (AI) was initiated by Cameroon Government in the northern regions (Far North, North and Adamawa) to improve the productivity of local breeds and increase national milk production. The Agricultural Productivity Improvement Program (APIP) / Support to Development of the Dairy Sector (SDDS) cofinanced by the European Union and Cameroon Government has been implemented. One of its objectives is to improve local dairy production through the use of AI, and thus to train, equip and structure the actors of the dairy sector to secure their incomes and improve their livelihoods. Despite numerous technical and economic support operations with the establishment of dairy projects and significant investments from breeders, the country remains largely dependent on imports which cost nearly 30 billion CFA francs in 2007 (MINEPIA, 2009). This dependence on imports is attributed to the lack of livestock management techniques, notably herd feeding, sanitary cover (Ebangi et al., 2011) and reproduction control (Bayemi et al., 2005a). However, the efforts made by the government also give rise to a controversial debate over past failures to intensify milk production. In order to guide the development of livestock programs, it is essential to 
understand beforehand the structure of the production units, the forms of organization and the strategies of production and reproduction. For this purpose, it is important to know breeders' characteristics as well as those of cattle farms and of herds benefiting from development programs to improve dairy productivity in Cameroon. This study was designed to establish a typology of cattle farms that could be selected for AI programs in the northern regions of Cameroon.

\section{MATERIALS AND METHODS}

\section{Study area}

This work was conducted from January to June 2017 in the northern regions of Cameroon (Far North, North and Adamawa). These regions were selected because they represent $83 \%$ of the national cattle population (Bouba, 2005) and reproductive biotechnologies are being popularized by the Cameroonian government.

The Far North region is located between $10^{\circ}$ and $13^{\circ} \mathrm{N}$, and $13^{\circ}$ and $15^{\circ} \mathrm{E}$; it covers an area of $34,262 \mathrm{~km}^{2}$. It is characterized by a Sudano-Sahelian climate with two seasons: a short rainy season (June to September) and a long dry season (October to May). Average annual rainfall is $400-1100 \mathrm{~mm}$, maximum temperatures reach $40^{\circ} \mathrm{C}$ in Maroua and $41^{\circ} \mathrm{C}$ in Kousseri between March and April, and minima $16-18^{\circ} \mathrm{C}$ between December and February.

The North region is located between $12^{\circ}$ and $16^{\circ} \mathrm{N}$, and $7^{\circ}$ and $10^{\circ} \mathrm{E}$; it covers an area of $66,090 \mathrm{~km}^{2}$. The tropical climate is of the Sudanian type with two seasons: a rainy season (May to September) and a dry season (October to April). Average annual rainfall is $100-1300 \mathrm{~mm}$, and minimum and maximum temperatures are $14^{\circ} \mathrm{C}$ in December and $40^{\circ} \mathrm{C}$ in April.

The Adamawa region is located between $6^{\circ}$ and $8^{\circ} \mathrm{N}$, and between $11^{\circ}$ and $15^{\circ} \mathrm{E}$; it covers an area of $72,000 \mathrm{~km}^{2}$. It is characterized by a Sudano-Guinean climate with two seasons, a rainy and a dry season. Sometimes up to seven months of rainfall are recorded per year with rainfall exceeding $1500 \mathrm{~mm}$. Minimum and maximum recorded temperatures are $15.2^{\circ} \mathrm{C}$ and $29^{\circ} \mathrm{C}$, respectively.

\section{Data collection}

The questionnaires were developed from personal interviews with breeders. The designed questions were entered with Sphinx Plus ${ }^{2}$ version 4.0 software. The interviews were carried out in fulfuldé (language spoken widely in the northern regions of Cameroon) directly with 54 breeders: 14 in the Far North, 10 in the North and 30 in Adamawa. The breeders were those retained in the previously mentioned program (APIP/SDDS). The questions concerned their location, ethnicity, age, level of education, main activity, and years of experience in the use of reproductive technologies in their farms. With regard to farms, the questions concerned the breeding system, presence of a cattle shed, fodder cultivation, practice of forage conservation, types of fodder conserved and supplements, grazing methods, sources of water and destination of products (milk or meat). With regard to herds, we collected information on the breeds, size of the herd, number of females/ males, age of females/males, quantity of milk per day per cow in the rainy and dry seasons, and recurrent diseases.

\section{Statistical analysis}

Typological analysis is an aggregative method for grouping individuals into segments on the basis of similarities. It offers the advantage of simplifying the information while freeing the main features (Schwartz, 1963). For the statistical analysis, SPAD version 5.5 software was used. For the typological analysis, 27 variables were selected and coded, of which thirteen (region, ethnic group, main activity, breed, source of water, pasture displacement, dip, sprayer, barn, forage, supplementation, milk and meat flow, preferred reproductive technology) were active nominal variables with two to five modalities. Ten were continuous illustrative variables (average age of animal, age of females and males, number of females and males, herd size, liters of milk in rainy and dry seasons, liters of milk per farm per year, number of hectares cultivated), and four were illustrative nominal variables (gender of the breeder, level of education, main diseases, supplements). These 14 illustrative variables did not contribute significantly to class formation.

We carried out the following analyses: multiple correspondence analysis (MCA), description of factorial axes, hierarchical ascending classification (HAC), tree break, class description and characterization of typology classes. The analysis of the histogram of the eigenvalues made possible the retainment of the first five factorial axes which collected at least $53.26 \%$ of all information. In order to form groups of farms with similar characteristics, the ascending hierarchical classification allowed to obtain a histogram of the index level and the analysis revealed two stall levels between levels 1-2 and 2-3. The cuts of the dendrogram were made at levels 2 and 3. The analysis allowed to identify two partitions with two and three classes, but that of the three classes was the most homogeneous according to the classification criteria used (Figure 1).

The Chi-square test was used to compare the modalities of the variable proportions for the three types to the significance threshold of $5 \%$.

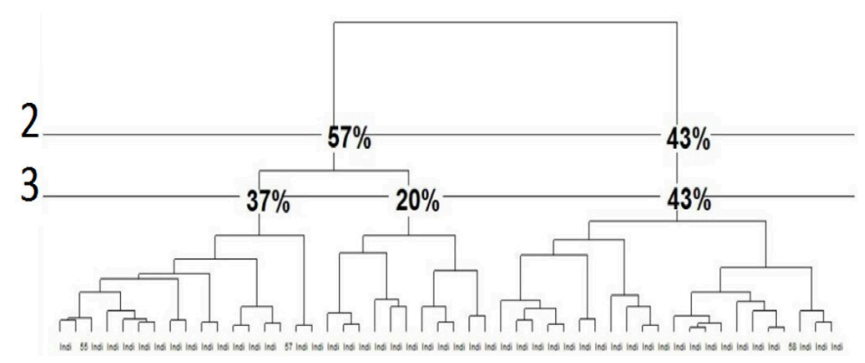

Figure 1: Hierarchical ascending classification dendrogram. Farms (Indi) were grouped together following their similarity to form a partition and the cuts of the dendrogram were made at levels 2 and 3.

\section{RESULTS}

\section{Characteristics of the cattle farms}

\section{Socioprofessional characteristics of breeders}

Farmers were predominantly Fulani $(81.5 \%)$ and men $(92.6 \%)$ (Table I). They were full-time agricultural producers (42.6\%), including cattle breeders and agropastoralists. Civil servants also represented more than a third of the sample. In the Adamawa, breeders had significantly $(\mathrm{p}<0.05)$ accumulated more years of experience $(5.5 \pm 3.7$ years) in AI than breeders from the North and Far North.

\section{Farm characteristics}

The semi-extensive system, where animals grazed on pastureland during the day and received supplement in the morning and/or evening after returning from pastures, was the most common method of breeding in the farms surveyed (87\%) (Table II). However, in the Adamawa, there were eight farms where animals did not go to natural pasture. The conservation of millet stems was significantly $(\mathrm{p}<0.05)$ the prerogative of farmers in the Far North as well as supplementation with cereals (18.5\%) and cotton hulls (11.1\%). The majority of milk was self-consumed or sold by $48.1 \%$ of the breeders and pasture surfaces were larger in Adamawa farms. 
Table I

Socio-occupational characteristics of breeders in Northern Cameroon

\begin{tabular}{|c|c|c|c|c|c|}
\hline Variables & Modalities & Adamawa (\%) & North (\%) & Far North (\%) & Total (\%) \\
\hline Gender & $\begin{array}{c}\text { Male } \\
\text { Female }\end{array}$ & $\begin{array}{c}29 \text { (53.7) } \\
1(1.9)\end{array}$ & $\begin{array}{c}10(18.5) \\
0(0.0)\end{array}$ & $\begin{array}{c}11(20.4) \\
3(5.6)\end{array}$ & $\begin{array}{c}50(92.6) \\
4(7.4)\end{array}$ \\
\hline Ethnic group & $\begin{array}{c}\text { Fulani } \\
\text { Toupouri } \\
\text { Mandara } \\
\text { Fali } \\
\text { Guidar }\end{array}$ & $\begin{array}{c}29(53.7) \\
1(1.9) \\
0(0.0)^{*} \\
0(0.0)^{*} \\
0(0.0)^{*}\end{array}$ & $\begin{array}{c}5(9.3) \\
2(3.7) \\
0(0.0)^{*} \\
2(3.7)^{*} \\
1(1.9)^{*}\end{array}$ & $\begin{array}{c}10(18.5) \\
1(1.9) \\
3(5.6)^{*} \\
0(0.0)^{*} \\
0(0.0)^{*}\end{array}$ & $\begin{array}{c}44(81.5) \\
4(7.4) \\
3(5.6) \\
2(3.7) \\
1(1.9)\end{array}$ \\
\hline Level of education & $\begin{array}{c}\text { None } \\
\text { Primary school } \\
\text { Secondary school } \\
\text { Higher education }\end{array}$ & $\begin{array}{c}9(16.7) \\
10(18.5) \\
5(9.3) \\
6(11.1)\end{array}$ & $\begin{array}{l}4(7.4) \\
2(3.7) \\
1(1.9) \\
3(5.6)\end{array}$ & $\begin{array}{l}0(0.0) \\
5(9.3) \\
4(7.4) \\
5(9.3)\end{array}$ & $\begin{array}{l}13(24.1) \\
17(31.5) \\
10(18.5) \\
14(25.9)\end{array}$ \\
\hline Main activity & $\begin{array}{l}\text { Cattle breeder } \\
\text { Agropastoralist } \\
\text { Civil servant } \\
\text { Trader }\end{array}$ & $\begin{array}{c}7(13.0) \\
10(18.5) \\
4(7.4 \%)^{*} \\
9(16.7)\end{array}$ & $\begin{array}{c}1(1.9) \\
2(3.7) \\
4(7.4)^{*} \\
3(5.6)\end{array}$ & $\begin{array}{c}1(1.9) \\
2(3.7) \\
11(20.4)^{*} \\
0(0.0)\end{array}$ & $\begin{array}{c}9(16.7) \\
14(25.9) \\
19(35.2) \\
12(22.2)\end{array}$ \\
\hline Age (years) & Mean \pm SD & $45.30 \pm 11.91$ & $45.60 \pm 12.29$ & $53.86 \pm 13.68$ & $47.57 \pm 12.77$ \\
\hline Experience (years) & Mean \pm SD & $5.50 \pm 3.68^{*}$ & $2.60 \pm 1.26^{*}$ & $2.21 \pm 0.58^{*}$ & $4.11 \pm 3.20$ \\
\hline Total & & $30(55.6)$ & $10(18.5)$ & $14(25.9)$ & $54(100)$ \\
\hline
\end{tabular}

* Significant difference; SD: standard deviation

Table II

Characteristics of farms according to the region in Northern Cameroon

\begin{tabular}{|c|c|c|c|c|c|}
\hline Variables & Modalities & Adamawa (\%) & North (\%) & Far North (\%) & Total $(\%)$ \\
\hline Breeding system & $\begin{array}{l}\text { Extensive } \\
\text { Semi-extensive } \\
\text { Intensive }\end{array}$ & $\begin{aligned} 1 & (1.9) \\
27 & (50.0) \\
& 2(3.7)\end{aligned}$ & $\begin{array}{c}3(5.6) \\
7(13.0) \\
0(0.0)\end{array}$ & $\begin{aligned} 1 & (1.9) \\
13 & (24.1) \\
0 & (0.0)\end{aligned}$ & $\begin{array}{c}5(9.3) \\
47(87.0) \\
2(3.7)\end{array}$ \\
\hline Source of water supply & $\begin{array}{c}\text { Water tower } \\
\text { Drilling } \\
\text { River } \\
\text { Well }\end{array}$ & $\begin{aligned} 5 & (9.3) \\
11 & (20.4) \\
19 & (35.2) \\
0 & (0.0)\end{aligned}$ & $\begin{array}{c}0(0.0) \\
2(3.7) \\
7(13.0) \\
1(1.9)\end{array}$ & $\begin{array}{c}1(1.9) \\
9(16.7) \\
6(11.1) \\
0(0.0)\end{array}$ & $\begin{array}{c}6(11.1) \\
22(40.7) \\
32(59.3) \\
1(1.9)\end{array}$ \\
\hline Pasture use & $\begin{array}{l}\text { Yes } \\
\text { No }\end{array}$ & $\begin{array}{l}22(40.7) \\
8(14.8)^{*}\end{array}$ & $\begin{array}{c}10(18.0) \\
0(0.0)^{*}\end{array}$ & $\begin{array}{c}14(25.9) \\
0(0.0)^{*}\end{array}$ & $\begin{array}{l}46(85.2) \\
8(14.8)\end{array}$ \\
\hline Dip use & $\begin{array}{l}\text { Yes } \\
\text { No }\end{array}$ & $\begin{array}{c}5(9.3) \\
25(46.3)\end{array}$ & $\begin{array}{c}1(1.9) \\
9(16.7)\end{array}$ & $\begin{array}{c}0(0.0) \\
14(25.9)\end{array}$ & $\begin{array}{c}6(11.1) \\
48(88.9)\end{array}$ \\
\hline Spray use & $\begin{array}{l}\text { Yes } \\
\text { No }\end{array}$ & $\begin{array}{l}18(33.3) \\
12(22.2)\end{array}$ & $\begin{array}{c}6(11.1) \\
4(7.4)\end{array}$ & $\begin{array}{c}9(16.7) \\
5(9.3)\end{array}$ & $\begin{array}{l}33(61.1) \\
21(38.9)\end{array}$ \\
\hline Presence of cattle shed & $\begin{array}{l}\text { Yes } \\
\text { No }\end{array}$ & $\begin{array}{l}10(18.5) \\
20(37.0)\end{array}$ & $\begin{array}{c}2(3.7) \\
8(14.8)\end{array}$ & $\begin{array}{c}2(3.7) \\
12(22.2)\end{array}$ & $\begin{array}{l}14(25.9) \\
40(74.1)\end{array}$ \\
\hline Type of fodder reserve & $\begin{array}{l}\text { Brachiaria ssp. } \\
\text { Millet stem }\end{array}$ & $\begin{array}{c}26(48.1) \\
0(0.0)^{*}\end{array}$ & $\begin{array}{l}7(13.0) \\
0(0.0)^{*}\end{array}$ & $\begin{array}{l}8(14.8) \\
5(9.3)^{*}\end{array}$ & $\begin{array}{c}41(75.9) \\
5(9.3)\end{array}$ \\
\hline No reserve & & $4(7.4)$ & $3(5.6)$ & $6(11.1)$ & $13(24.1)$ \\
\hline Type of supplement & $\begin{array}{c}\text { Cake } \\
\text { Concentrate } \\
\text { Cereal bran } \\
\text { Cotton hull }\end{array}$ & $\begin{array}{c}26(48.1) \\
7(13.0) \\
3(5.6)^{*} \\
0(0.0)^{*}\end{array}$ & $\begin{array}{c}10(18.5) \\
1(1.9) \\
6(11.1)^{*} \\
0(0.0)^{*}\end{array}$ & $\begin{aligned} 14 & (25.9) \\
1 & (1.9) \\
10 & (18.5)^{*} \\
6 & (11.1)^{*}\end{aligned}$ & $\begin{array}{c}50(92.6) \\
9(16.7) \\
19(35.2) \\
6(11.1)\end{array}$ \\
\hline No supplement & & $2(3.7)^{*}$ & $0(0.0)^{*}$ & $0(0.0)^{*}$ & $2(3.7)$ \\
\hline $\begin{array}{l}\text { Product destination } \\
\text { (milk) }\end{array}$ & $\begin{array}{c}\text { Shepherd } \\
\text { Consumption + shepherd } \\
\text { Sale } \\
\text { Consumption + sale }\end{array}$ & $\begin{array}{c}9(16.7) \\
4(7.4) \\
6(11.1) \\
11(20.4)\end{array}$ & $\begin{array}{c}0(0.0) \\
2(3.7) \\
1(1.9) \\
7(13.0)\end{array}$ & $\begin{array}{c}1(1.9) \\
5(9.3) \\
0(0.0) \\
8(14.8)\end{array}$ & $\begin{array}{c}10(18.5) \\
11(20.4) \\
7(13.0) \\
26(48.1)\end{array}$ \\
\hline Pasture land (ha) & Mean \pm SD & $10.03 \pm 12.76^{*}$ & $2.60 \pm 4.1^{*}$ & $2.29 \pm 4.12^{*}$ & $6.65 \pm 10.53$ \\
\hline Total & & $30(55.6)$ & $10(18.5)$ & $14(25.9)$ & $54(100)$ \\
\hline
\end{tabular}

* Significant difference 


\section{Herd characteristics}

The main breeds found in Adamawa were the Gudali zebu (53.7\%), Gudali x Holstein crossbred (44.4\%) and Holstein (16.7\%). In the Far North and North the breeds encountered were the Djafoun (44.4\%) and Akou zebu (5.6\%) (Table III). Foot and mouth was the recurrent disease $(96.3 \%)$, followed by trypanosomosis $(77.8 \%)$.

\section{Typology}

The ascending hierarchical classification revealed three classes of cattle farms (Figure 2; Table IV).

\section{Type I breeders}

The type I breeders represented $37 \%$ of the breeders $(n=20)$. There was no infrastructure on the farms and the source of water remained generally the river (55.6\%). On average, they consisted of $31 \pm 25$ head, $26 \pm 20$ females and $5 \pm 8$ males with a sex ratio of 0.18 . They were characterized by a small grazing area of $4.9 \pm 5$ ha. Although forage was grown to feed the animals during the harsh season, milk production per day per cow in the rainy $(1.8 \pm 1.3 \mathrm{~L})$ and dry $(1.3 \pm 1 \mathrm{~L})$ seasons, and per year $(682 \pm 1327 \mathrm{~L})$ was the lowest. The milk from these farms was mainly kept for home consumption and calves (80\%). Gudali and crossbreds grazed during the day and were scarcely supplemented when returning from grazing. The preferred reproductive practice was natural mating (56\%). These farms could be classified in the extensive system. They were only found in the Adamawa where breeders are Fulani, illiterate at $45 \%$. The main activities of these farmers were livestock breeding and trade.

\section{Type II breeders}

The type II breeders represented $18.5 \%$ of the farms $(n=10)$ and were characterized by the size of their herd with $50 \pm 26$ head, which consisted of $39 \pm 23$ females and $7 \pm 9$ males with a sex ratio of 0.18 . They used the largest grazing areas $(18 \pm 18$ ha) compared to the average of the total sample (6.6 \pm 10 ha). Similarly, the dairy production per cow per day was higher in the rainy $(4.4 \pm 3.7 \mathrm{~L})$ and dry $(3$ $\pm 3 \mathrm{~L})$ seasons, and per herd per year $(9493 \pm 16371 \mathrm{~L})$ than in types I and III. The milk produced was mainly for sale (63.7\%). The animals bred were Holstein (45.4\% of the breeders used them) and crossbreds (Gudali x Holstein) (72.7\%). They preferred AI (100\%) as a reproductive technology to improve the genetic material of their herd. The animals did not go to pasture but were fed in cattle sheds and supplemented with oilcakes (100\%) and concentrate (36.4\%), water came from water towers or drills. These farms could be qualified as semi-intensive and were only found in Vina Division (Adamawa). This system was owned by the Fulani. Some of them had a secondary (36.4\%) or university (36.4\%) level of education, many were civil servants $(45.5 \%)$ or traders $(27.3 \%)$.

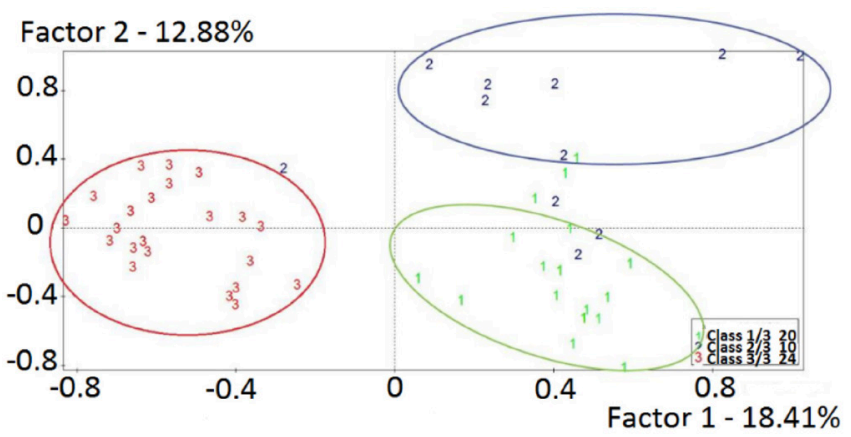

Figure 2: Projection of the farm classes on the factorial planes 1, 2.

\section{Table III}

Characteristics of cattle herds in Northern Cameroon

\begin{tabular}{|c|c|c|c|c|c|}
\hline Variables & Modalities & Adamawa (\%) & North (\%) & Far North (\%) & Total (\%) \\
\hline Breed & $\begin{array}{l}\text { Djafoun } \\
\text { Akou } \\
\text { Gudali } \\
\text { Holstein } \\
\text { Crossbred }\end{array}$ & $\begin{array}{c}2(3.7)^{*} \\
1(1.9)^{*} \\
29(53.7)^{*} \\
8(14.8)^{*} \\
21(38.9)\end{array}$ & $\begin{array}{c}9(16.7)^{*} \\
2(3.7)^{*} \\
0(0.0)^{*} \\
1(1.9)^{*} \\
1(1.9)\end{array}$ & $\begin{array}{c}13(24.1)^{*} \\
0(0.0)^{*} \\
0(0.0)^{*} \\
0(0.0)^{*} \\
2(3.7)\end{array}$ & $\begin{aligned} 24 & (44.4) \\
3 & (5.6) \\
29 & (53.7) \\
9 & (16.7) \\
24 & (44.4)\end{aligned}$ \\
\hline Recurrent disease & $\begin{array}{c}\text { Abortion } \\
\text { Non-delivery } \\
\text { Trypanosomosis } \\
\text { Foot and mouth } \\
\text { CBPP } \\
\text { Dermatophylosis }\end{array}$ & $\begin{array}{c}16(29.6)^{*} \\
2(3.7)^{*} \\
28(51.9) \\
29(53.7) \\
2(3.7)^{*} \\
6(11.1)\end{array}$ & $\begin{array}{c}0(0.0)^{*} \\
0(0.0)^{*} \\
5(9.3) \\
10(18.5) \\
3(5.6)^{*} \\
0(0.0)\end{array}$ & $\begin{array}{c}0(0.0)^{*} \\
0(0.0)^{*} \\
9(16.7) \\
13(24.1) \\
11(20.4)^{*} \\
1(1.9)\end{array}$ & $\begin{aligned} 16 & (29.6) \\
2 & (3.7) \\
42 & (77.8) \\
52 & (96.3) \\
16 & (29.6) \\
7 & (13.0)\end{aligned}$ \\
\hline Herd size & Mean \pm SD & $38.87 \pm 26.85$ & $48.10 \pm 32.17$ & $37.64 \pm 24.85$ & $40.26 \pm 27.13$ \\
\hline Number of females & Mean \pm SD & $31.50 \pm 21.29$ & $33.60 \pm 21.33$ & $25.86 \pm 17.14$ & $30.43 \pm 20.14$ \\
\hline Average age of females (years) & Mean \pm SD & $5.77 \pm 1.19$ & $4.60 \pm 0.97$ & $5.50 \pm 2.14$ & $5.48 \pm 1.50$ \\
\hline Number of males & Mean \pm SD & $5.63 \pm 8.30$ & $13.70 \pm 12.76$ & $11.00 \pm 10.78$ & $8.52 \pm 10.26$ \\
\hline Average age of males (years) & Mean \pm SD & $2.60 \pm 1.98$ & $4.00 \pm 1.25$ & $3.50 \pm 1.40$ & $3.09 \pm 1.79$ \\
\hline Milk/cow/day/rainy season (L) & Mean \pm SD & $3.03 \pm 2.70$ & $2.80 \pm 1.55$ & $2.57 \pm 0.76$ & $2.87 \pm 2.14$ \\
\hline Milk/cow/day/dry season (L) & Mean \pm SD & $1.77 \pm 2.03$ & $1.40 \pm 1.43$ & $1.57 \pm 1.55$ & $1.65 \pm 1.79$ \\
\hline Milk/year (L) & Mean \pm SD & $\begin{array}{c}3712.33 \\
\pm 10585.18\end{array}$ & $\begin{array}{c}2317.50 \\
\pm 3317.84\end{array}$ & $\begin{array}{c}3042.86 \\
\pm 7742.86\end{array}$ & $\begin{array}{c}3280.46 \\
\pm 8841.84\end{array}$ \\
\hline Total & & $30(55.6)$ & $10(18.5)$ & $14(25.9)$ & $54(100)$ \\
\hline
\end{tabular}

* Significant difference; CBPP: contagious bovine peripneumonia 


\section{Table IV}

Main characteristics of the three types of breeders in Northern Cameroon

\begin{tabular}{|c|c|c|c|}
\hline Variables & Type I breeders (\%) & Type II breeders (\%) & Type III breeders (\%) \\
\hline & $20(37)$ & $10(18.5)$ & $24(44.5)$ \\
\hline Region & Adamawa (100) & Vina (Adamawa): (100) & $\begin{array}{c}\text { North (39.13) } \\
\text { Far North (60.87) }\end{array}$ \\
\hline Gender & $\begin{array}{l}\text { Male (95) } \\
\text { Female (5) }\end{array}$ & $\begin{array}{l}\text { Male (100) } \\
\text { Female (0.0) }\end{array}$ & $\begin{array}{l}\text { Male (87) } \\
\text { Female (13) }\end{array}$ \\
\hline Ethnic group & Fulani (100) & Fulani (100) & $\begin{array}{l}\text { Fulani (60.9) } \\
\text { Other (34.7) }\end{array}$ \\
\hline Level of education & None (45) & Higher education (36.4) & Higher education (30.4) \\
\hline Main activity & $\begin{array}{l}\text { Cattle breeder (35) } \\
\text { Trader (35) }\end{array}$ & $\begin{array}{l}\text { Civil servant (45.5) } \\
\text { Trader (27.3) }\end{array}$ & $\begin{array}{c}\text { Civil servant (65.2) } \\
\text { Agropastoralist (17.4) }\end{array}$ \\
\hline Breed & $\begin{array}{l}\text { Gudali (100) } \\
\text { Crossbred (100) }\end{array}$ & $\begin{array}{l}\text { Holstein }(45.45) \\
\text { Crossbred }(72.7)\end{array}$ & $\begin{array}{l}\text { Djafoun (95.65) } \\
\text { Akou (8.7) }\end{array}$ \\
\hline Pasture use & Yes (100) & No (100) & Yes (100) \\
\hline Type of supplement & Cake (5) & $\begin{array}{c}\text { Cake (100) } \\
\text { Concentrate (36.4) }\end{array}$ & $\begin{array}{c}\text { Cake (95.7) } \\
\text { Cereal bran (73.9) } \\
\text { Cotton hull }(26.09)\end{array}$ \\
\hline Source of water supply & River (55.6) & Water tower (54.5) & River $(47.8 \%)$ \\
\hline Presence of cattle shed & No (100) & Yes (100) & No $(82.6 \%)$ \\
\hline Herd size & $31.25 \pm 25.56$ & $49.91 \pm 26.36$ & $43.26 \pm 27.77$ \\
\hline Number of females & $26.20 \pm 20.48$ & $39.09 \pm 23.02$ & $31.04 \pm 19.44$ \\
\hline Number of males & $4.85 \pm 7.78$ & $7.09 \pm 8.92$ & $11.70 \pm 10.87$ \\
\hline Sex ratio & 0.18 & 0.18 & 0.37 \\
\hline Pasture land (ha) & $4.90 \pm 5.00$ & $18.09 \pm 17.81$ & $2.52 \pm 4.10$ \\
\hline Milk/cow/day/rainy season (L) & $1.80 \pm 1.32$ & $4.45 \pm 3.72$ & $2.39 \pm 0.75$ \\
\hline Milk/cow/day/dry season (L) & $1.33 \pm 0.98$ & $3.05 \pm 3.00$ & $1.39 \pm 1.30$ \\
\hline Milk/year/herd (L) & $682.25 \pm 1326.93$ & $9493.18 \pm 16371.56$ & $2546.74 \pm 6255.05$ \\
\hline Destination of products (milk) & $\begin{array}{c}\text { Shepherd } \\
+ \text { consumption (80) }\end{array}$ & Sale (63.7) & $\begin{array}{l}\text { Consumption } \\
+ \text { sale }(52.2)\end{array}$ \\
\hline $\begin{array}{l}\text { Reproductive technology } \\
\text { preferred }\end{array}$ & Natural mating (56) & $\mathrm{Al}(100)$ & Natural mating (98) \\
\hline
\end{tabular}

AI: artificial insemination

\section{Type III breeders}

The type III breeders represented $44.5 \%$ of the farms $(n=24)$ with an average herd size of $43 \pm 28$ head, $31 \pm 19$ females and $12 \pm 11$ males with a sex ratio of 0.37 . They used small grazing areas $(2.5 \pm 4.1 \mathrm{ha})$. Milk production per cow per day in the rainy and dry seasons, and per year was $2.4 \pm 0.7 \mathrm{~L}, 1.4 \pm 1.3 \mathrm{~L}$, and $2546 \pm 6255 \mathrm{~L}$, respectively. Milk was mostly produced by the Djafoun (95.6\%) and the Akou $(8.7 \%)$. For $52.2 \%$ of the farmers, the milk produced was mainly for home consumption and for sale. The main reproductive practice was natural mating (98\%). The animals were sent to the pasture in the morning and received supplements, which were mostly made up of cake $(95.7 \%)$, cereal brand $(73.9 \%)$ and cotton hulls $(26.1 \%)$, in the morning or evening. The main sources of water were rivers and drills. The farms were semi-extensive and found in the North and Far North, where $60.9 \%$ of the farmers were Fulani and $38.1 \%$ belonged to other ethnic groups (Toupouri, Mandara, Fali and Guidar). The farmers were either civil servants or agropastoralists.

\section{DISCUSSION}

\section{Characterization of breeders, farms and herds}

The breeders surveyed were mostly Fulani (81.5\%), which is in agreement with the ethnological data of Cameroon reported by Barbier (1983) who calls them 'populations of breeders'. Boukar et al. (2015) in the western highlands of Cameroon, and Somda et al. (2004) in Guinea also report $72.6 \%$ and $98.9 \%$ of Fulani herders, respectively. On the other hand, Kouamo et al. (2009) in the region of Thies in Senegal observe that only $10.3 \%$ of the breeders are Fulani. This difference is due to the fact that the Wolof $(51 \%)$ and Serere $(38.1 \%)$ are the majority in this region of Senegal. The male and female proportions were similar to a study conducted by Boukar et al. (2015), and Somda et al. (2004). Women's initiative in animal production shows the importance of dairy production in diversifying women's income as they seek financial empowerment. Dieng et al. (2014) note a hierarchy in the profession in which, due to cultural considerations of traditional African societies, women 
are more involved in marketing and processing milk, whereas men are involved in production. This study showed that civil servants also represented more than a third of the sample. Currently, dairy production is a source of income for new investors who are increasingly involved in animal production and processing of their products (Dia-Sow et al., 2007). However, it should be noted that civil servants were accessed more easily than other categories of breeders in this study.

The semi-extensive system was the most widely used (87\%). Studies carried out by Blama et al. (2016) in Far North Cameroon, and Asseu (2010) in Kaolack (Senegal) report that $66.6 \%$ and $87.2 \%$, respectively, of the surveyed farmers practice the extensive system, i.e. natural pasture is the main source of feed. However, studies conducted by Kaouche et al. (2012) in Algeria, and Hiernaux et al. (2016) in Niger report that $92.8 \%$ and $88.1 \%$ of the farmers, respectively, practice supplementation and zero grazing. The restriction of grazing areas, the degradation of pastures and inadequate feeding are factors of failure of any reproductive technology, and may explain the transition from the extensive to the semi-extensive system in the present study. The study also showed that $96.3 \%$ of farmers gave supplements and $75.9 \%$ of them had forage reserves. These reserves consisted mainly of Brachiaria spp. and millet stems. This suggests that Brachiaria spp. and cereal straw are the staple feed for farms benefiting from dairy productivity enhancement in the study area. Supplementation was made of cereal meals and brand, whereas in suburban Dakar supplements consist mainly of brewery byproducts (Ba Diao et al., 2006).

The main breeds used were local (Gudali) and crossed breeds (Gudali x Holstein) as reported by several authors (Kibwana et al., 2012; Mingoas et al., 2014; Kamga et al., 2001). For local breeds, milk production is estimated at 1.5 to 3 liters per day (Messine et al., 1995). In a semiintensive or intensive system, Bayemi et al. (2005b) report that in the rainy season, the crossbred and the pure Holstein produce daily 8-15 L and $25 \mathrm{~L}$, respectively. They note that despite their relatively difficult adaptation in Cameroon, exotic breeds have better dairy production and reproductive parameters ( 24 months for sexual maturity) than local breeds (36 months). Thus, artificial insemination is a good means to increase the milk production of local cows thanks to the genetic progress of selected bulls while preserving the natural adaptability of local breeds. The present study showed that the foot-and-mouth virus circulated in this part of Cameroon. Mingoas et al. (2014) report that foot and mouth $(14.5 \%)$ is the main disease after trypanosomosis $(74.5 \%)$. This shows that animal health is not sufficiently under control in sub-Saharan Africa and Cameroon in particular. Consequently, it affects genetic progress and causes economic losses.

\section{Classes of farms}

Type I breeders practiced typical extensive animal production, i.e. they limited inputs making it necessary for them to move the herds over long distances to search for pasture. These characteristics are similar to those of the so-called familial system described by Uddin et al. (2013) in Bangladesh. The low production of milk per cow in both the rainy and dry seasons, despite the presence of crossbreds in the herds, is inherent to the extensive system applied. Lhoste (1991) reports that crossbreds from a cross between local and exotic breeds are not usable in an extensive regime. According to Bouyer (2006), it is hard to implement reproductive technologies in this system, particularly AI, because it is very difficult to keep the appointments for insemination since the breeder and his herd move with the seasons and available pasture and water. Moreover, the practice of $\mathrm{AI}$ is made tedious from the lack of basic infrastructure. Dairy production is mainly oriented toward home consumption, which can be explained by the low productivity of the animals and the lack of reliable information on the milk market. OderoWaitituh (2017) and Dia-Sow et al. (2007) report that small-scale family farms face production and marketing constraints, including fluctuations in the quantities offered, lack of storage, processing facilities, transportation, milk delivery in large shopping areas, and reduced access to AI service. According to farmers of this type, to sell more milk, they would have to obtain a daily production level of at least five liters per day per cow. This implies the improvement of the genetic material as well as of animal feeding.

Type II farm characteristics, described as semi-intensive systems, were similar to those of large dairy farms reported by Sraïri et al. (2003) in Morocco and Bir et al. (2014) in Algeria, where grazing areas and herd size are the most important, and feeding (hay and concentrate) combined with supplementation was highest. In order to intensify dairy farms, this type of breeders deserves particular attention for development programs because their success will convince skeptical farmers to use AI. Understanding the added value of innovation in animal production (e.g. AI, forage production, feeding to the barn), will be facilitated by a higher level of education. Dantas et al. (2016) in the Amazonian State in Brazil and Uddin et al. (2013) in Bangladesh report that in farms where the level of education is high, the adoption of new reproductive technologies, use of dietary supplements, herd management and reproductive management are enhanced and more widespread. Therefore, it appears to be the ideal type for the use of new reproductive technologies. These farms based in Vina Division offer potentialities for the development of reproductive technologies. Cameroon would benefit from investing in the organization of this type of farms and the development of basal infrastructures for the revival of the dairy sector. Several countries have made the move to meet the challenge of dairy sector productivity, e.g. China, which has undertaken important policies in this area through the 'New Hope Dairy Group' project (World Bank, 1995).

Type III corresponds to the semi-extensive system in which breeders are settled. Agricultural and industrial by-products (e.g. cotton hulls, cotton grains) are distributed to the animals after the return from pastures. This confirms the characteristics of the farms described by Kibwana et al. (2012), Blama et al. (2016), and Dia-sow et al. (2007). The share of land dedicated to forage production for animal feed is the lowest in the sample since breeding is not the only activity of these farmers; they also grow crops (17.4\% agropastoralists). Pham Duy Khanh et al. (2016) report that family farms have the smallest forage areas because they leave a relatively large share to food crops. This type offers favorable conditions to improve milk production by the use of AI because of the availability of crop residues (e.g. cereal straw, millet stalk, cotton hulls). According to Bouyer (2006), this type seems to be better adapted than type I to the use of reproductive technologies since transhumance is not practiced and the animals are often better fed than in pastoral farming. However, industry by-products were either insufficient or too expensive and explained the undernourishment of the animals, which did not allow the externalization of the dairy potential of the genetic resources used. These constraints were similar to those reported by other authors (Dia-Sow, 2004; Dia-Sow et al., 2005). The domestic consumption and sale of milk in this type of farm can significantly contribute to meet the local demand for milk, especially if the existing genetic material is to be improved. Messine et al. (1995) report that crossbreeding local with exotic breeds resulted in products whose production performance almost doubled compared to that of local breeds.

Informal marketing and long distance from the market limit the demand and supply of domestically produced milk and dairy products in local markets. Breeders who are far from urban centers (types I and III) cannot easily sell their milk. Consequently, cows are milked once a day to sustain family needs. At farm level, there are no cooling or storage facilities for fresh milk, neither processing facilities nor technical knowhow. Thus, traditional treatments are performed frequently by women to obtain the following local products: pendidam (fermented milk), kindirmu (local yogurt), lebol (butter), nebam (butter oil) and sour milk (Bayemi et al. 2005a). In suburban areas (Vina), there is no milk collection system for processing, and milk is mainly sold (63.7\%) every day by 
the farmer directly to the consumers of the city of Ngaoundere, the rest is self-consumed. It is necessary to set up a dairy sector in this area for the successful intensification of milk production.

\section{- CONCLUSION}

This typology reveals that factors such as the environment and its resources seem to be determinant in the formation of breeders, and the choice of any reproductive technology depends on the system used. The type II farms in Vina Division offer potentials for the development of AI practices, dairy production, and breeders of these farms could be considered as pilots for the revival of the dairy sector in Cameroon. For a successful intensification of milk production, it is necessary to train farmers to manage a dairy herd, organize the milk market, and set up an efficient system of milk collection and a milk cold chain from the farmer to the consumer.

\section{Acknowledgments}

The authors are grateful to the regional and departmental delegations of animal husbandry, fisheries and animal industries in the northern regions for their considerable contribution to the provision of lists of breeders who have benefited from dairy productivity improvement projects in the area.

\section{REFERENCES}

ACDIC., 2006. Filière laitière au Cameroun, 69 p. www.cfsi.asso.fr >20etude-lait-cameroun (consulté 26 déc. 2017)

Asseu K.C.A., 2010. Evaluation du degré d'acceptation de I'insémination artificielle bovine à Kaolack au Sénégal. Thèse Méd. Vét., Université de Dakar, Sénégal, 121 p.

Ba Diao M., Dieng A., Seck M.M., Ngomibé R.C. 2006. Feeding practices and productivity of dairy cows in the suburban area of Dakar. Rev. Elev. Med. Vet. Pays Trop., 59 (1-4): 43-49, doi : 10.19182/remvt.9953

Barbier J.C., 1983. Les groupes ethniques et langue du Cameroun. In : L'Encyclopédie de la République unie du Cameroun. NEA, Douala, Cameroun, 239-260

Bayemi P.H., Bryant M.J., Perera B.M.A.O., Mbanya J.N., Cavestany D., Webb E.C., 2005a. Milk production in Cameroon: A review. Livest. Res. Rural Dev., 17 (6), www.Irrd.org/lrrd17/6/baye17060.htm

Bayemi P.H., Bryant M.J., Pingpoh D., Imele H., Mbanya J., Tanya V., Cavestany D. et al., 2005b. Participatory rural appraisal of dairy farms in the North West province of Cameroon. Livest. Res. Rural Dev., 17 (6), www.Irrd.org/ Irrd17/6/baye17059.htm

Bir A., Yakhlef H., Madani T., 2014. Diversité des exploitations agricoles laitières en zone semi-aride de Sétif (Algérie). Livest. Res. Rural Dev., 26 (2), www.Irrd.org/lrrd26/2/bir26026.htm

Blama Y., Ziebe R., Rigolot C., 2016. Typologie des élevages sédentaires en zone semi-aride : cas du Cameroun. Livest. Res. Rural Dev., 28 (5), www. Irrd.org/lrrd28/5/blam28087.html

Bouba M., 2005. Evolution et situation actuelle de l'élevage au Cameroun. Rapport de synthèse. Minepia, Cameroun, 42 p.

Boukar O., Fotso Kenmogne P.R, Yaya M., Manjeli Y., 2015. Caractéristiques socio-économiques et techniques de l'élevage bovin à viande dans le département du Noun, région de l'Ouest-Cameroun. Livest. Res. Rural Dev., 27 (6), www.Irrd.org/Irrd27/6/fots27110.html

Bouyer B., 2006. Bilan et analyse de I'utilisation de l'insémination artificielle dans les programmes d'amélioration génétique des races laitières en Afrique soudano-sahélienne. Thèse Méd. Vét., Université de Lyon, France

Dantas V.V., Oaigen R.P., Santos M.A.S., Marques C.S.S., Silva F., 2016. Typology of dairy production systems in the Eastern Amazon, Pará, Brazil. Livest. Res. Rural Dev., 28 (6), www.Irrd.org/lrrd28/6/dant28109.htm

Dia-sow F., 2004. L'embouche paysanne, un exemple d'adaptation de l'élevage traditionnel à la nouvelle situation agricole dans le bassin arachidier au Sénégal. Cah. Agric., $13:$ 211-219
Dia-sow F., Somda J., Kamuanga M., Diop M., Cissé W., Maal I., Ndiaye S., 2005. Caractérisation socio-économique de la filière laitière dans le Bassin arachidier du Sénégal : dotation en ressources productives et rentabilité économique comparative des bovins locaux et métis. ITC, Banjul, The Gambia, 50 p. (Socio-economic paper ; 5)

Dia-sow F., Somda J., Kamuanga M., 2007. Dynamics of the dairy subsector in the Sahelian area: Milk supply and demand in the central agropastoral zone of Senegal. Rev. Elev. Med. Vet. Pays Trop., 60 (1-4): 77-88, doi : 10.19182/remvt.9980

Dieng K., Kalandi M., Sow A., Millogo V., Ouedraogo G.A., Sawadogo G.J., 2014. Profil socio-économique des acteurs de la chaine de valeur lait local à Kaolack au Sénégal. RASPA, 12 (3-4) : 161-168

Ebangi A.L., Erasmus G.J., Mbah D.A., Tawah C.L., Ndofor-Foleng H.M., 2011. Evaluation of level of inheritance in the growth traits in the Gudali and Wakwa beef cattle breeds of Adamawa, Cameroon. Livest. Res. Rural Dev., 23 (6), www.Irrd.org/Irrd23/6/eban23139.htm

Hiernaux P., Kalilou A., Zezza A., Augustine A., Ayantunde A.A., Giovanni F., 2016. Milk offtake of cows in smallholder farms of semiarid Sahel: low yields with high value! Rev. Elev. Med. Vet. Pays Trop., 69 (4): 143-153, doi: 10.19182/remvt.31199

Kamga P., Mbanya J.N., Awah N.R., Mbohou Y., Manjeli Y., Nguemdjom A., Kamga Pamela B., et al., 2001. Effect of the calving season and zootechnical parameters on milk yield in the western highlands of Cameroon. Rev. Elev. Med. Vet. Pays Trop., 54 (1): 55-61, doi : 10.19182/remvt.9807

Kaouche S., Boudina M., Ghezali S., 2012. Évaluation des contraintes zootechniques de développement de l'élevage bovin laitier en Algérie : cas de la wilaya de Médéa. Rev. Nat. Tech., 6 : 85-92

Kibwana D.K., Makumyaviri A.M., Hornick J.L., 2012. Extensive farming practices and cattle performances of the local breed or crossed with exotic dairy breeds in the Democratic Republic of Congo. Rev. Elev. Med. Vet. Pays Trop., 65 (3-4): 67-74, doi : 10.19182/remvt.10125

Kouamo J., Nkolo S., Leye A., Mouiche M., Ouedraogo G.A., Sawadogo. G.J., 2009. Caractéristiques structurelles et fonctionnelles des élevages bovins pratiquant l'insémination artificielle en milieu villageois au Sénégal : cas de la région de Thiès. In : XVII es journées médicales, pharmaceutiques, odontostomatologie et vétérinaires, Dakar, Sénégal 23-26 fév.

Lhoste P., 1991. Cattle genetic resources of West Africa. In: Cattle genetic resources (Ed. Hickman C.G.). Elsevier Science, Amsterdam, Netherlands, 73-89

Messine O., Tanya V.N., Mbah D.A., Tawah C.L., 1995. Ressources génétiques animales du Cameroun. Passé, présent et avenir : Le cas des ruminants. Anim. Genet. Resour. Inf., 16: 51-69

MINEPIA, 2009. Schéma directeur pour le développement des filières de I'élevage au Cameroun. Vol. II: Cartographie des filières. Yaoundé, Cameroun, $82 \mathrm{p}$.

MINEPIA, 2013. Document de politique du ministère de I'Elevage, des Pêches et des Industries animales. Yaoundé, Cameroun, 29 p.

MINEPIA, 2015. Elevage et pêche. Annuaire statistique du Cameroun. Yaoundé, Cameroun, 12 p.

Mingoas K.J.P., Zoli P.A., Tchoumboue J., Nyoungui E.J., Toukala J.P., 2014 Socio-economic characteristics and husbandry practices of cattle breeders in the Vina division, Cameroon. Int. J. Livest. Prod., 5 (3): 36-46, doi: 10.5897/IJLP12.020

Odero-Waitituh J.A., 2017. Smallholder dairy production in Kenya; a review. Livest. Res. Rural Dev., 29 (7), www.Irrd.org/lrrd29/7/atiw29139.html

Pham Duy Khanh K., Duteurtre G., Cournut S., Messad S., Dedieu B., Hostiou N., 2016. Characterizing dairy farm diversity and sustainability in Vietnam: Case study in suburban Hanoi. Rev. Elev. Med. Vet. Pays Trop., 69 (4): 131-141, doi: 10.19182/remvt.31198

Schwartz D., 1963. Méthodes statistiques à l'usage des médecins et biologistes, $3^{e}$ édn. Flammarion, Paris, France, 340 p.

Somda J., Keita K., Kamuanga M., Diallo M.B., 2004. Diagnostic des systèmes d'élevage peri-urbain en Moyenne Guinée : Analyse socio-économique des exploitations en production laitière dans la commune urbaine de Labé. Socio-economic working paper No 3. International Trypanotolerance Centre, Banjul, The Gambia, $44 \mathrm{p}$.

Sraïri M.T., Leblond J.M., Bourbouze A., 2003. Dairy and/or beef production: Diversity of $y$ in Gharb irrigated area, Northern Morocco. Rev. Elev. Med. Vet. Pays Trop., 56 (3-4): 177-186, doi : 10.19182/remvt.9862

Uddin M.M., Sultana M.N., Peters K.J., 2013. Participatory rural appraisal to characterize dairy production systems in Bangladesh. Livest. Res. Rural Dev., 25 (2), www.lrrd.org/lrrd25/2/uddi25029.htm

World Bank, 1995. World development report 1995: workers in an integrating world. Oxford University Press, Oxford, UK, 265 p. 


\section{Résumé}

Kouamo J., Pa-ana P. Typologie des fermes bovines dans les régions du nord du Cameroun

La présente étude, menée dans les élevages bovins des régions du nord du Cameroun, a eu pour objectif d'établir la typologie des exploitations afin de révéler les caractéristiques structurelles et fonctionnelles pouvant être sélectionnées dans un programme d'insémination artificielle. Une enquête a été réalisée auprès de 54 éleveurs. Les résultats ont montré qu'ils étaient majoritairement de l'ethnie peuhle (81,5\%) avec une prédominance d'hommes $(92,6 \%)$. Leur niveau d'éducation était le primaire $(31,5 \%)$, le secondaire $(18,5 \%)$ et le supérieur $(25,9 \%)$. Ils avaient une activité de production agricole à temps plein $(42,6 \%)$, élevage bovin et agropastoralisme. Les fonctionnaires représentaient plus du tiers de l'échantillon. La structure génétique des troupeaux était dominée par des races locales : 53,7 \% de zébus Gudali, 44,4\% de Djafoun et $5,6 \%$ d'Akou. De plus, 44,4 \% élevaient des races croisées et $16,7 \%$ des Holstein. Une analyse des correspondances multiples a été effectuée pour déterminer la typologie des exploitations étudiées. En fonction des caractéristiques structurelles (taille du troupeau, superficie fourragère, productivité laitière par vache et par jour, et infrastructure connexe) et fonctionnelles (alimentation, gestion du troupeau, choix technologique) des fermes, trois types ont été identifiés. Les éleveurs de type I $(37 \%)$ pratiquaient le système extensif et ceux de type II (18,5\%) le système semi-intensif. Ils étaient présents dans la région d'Adamawa et préféraient, respectivement, la saillie naturelle (56\%) et l'insémination artificielle (100\%) comme moyen de reproduction. Les éleveurs de type III $(44,5 \%)$ pratiquaient le système semi-extensif. Ils n'étaient présents que dans les régions du Nord et de l'Extrême-Nord et ils préféraient la saillie naturelle (98\%) comme moyen de reproduction. Les agriculteurs de type II étaient localisés dans la division de Vina (Adamawa) et présentaient les meilleures potentialités avec la pratique de l'insémination artificielle. Ces éleveurs peuvent être considérés comme des pilotes pour la relance de la filière laitière dans cette partie du Cameroun.

Mots-clés : Bos indicus, insémination artificielle, typologie, accouplement, production laitière, Cameroun

\section{Resumen}

Kouamo J., Pa-ana P. Tipología de fincas de ganado en las regiones norteñas de Camerún

El objetivo del presente estudio fue el de establecer la tipología de las fincas de ganado en las regiones norteñas de Camerún, con el fin de revelar las características estructurales y funcionales que podrían ser seleccionadas para un programa de inseminación artificial. Se llevó a cabo una encuesta entre 54 criadores. Los resultados mostraron que los finqueros fueron predominantemente del grupo étnico Fulani (81,5\%), con predominancia de hombres $(92,6 \%)$. Los niveles de educación fueron primaria $(31,5 \%)$, secundaria $(18,5 \%)$ y superior $(25,9 \%)$. Tuvieron una productividad agrícola tiempo completo $(42,6 \%)$, cría de ganado y agro pastoral. Los empleados públicos representaron más de un tercio de la muestra. La estructura genética de los hatos fue dominada por razas locales: 53,7\% cebúes Gudali, 44,4\% Djafoun y 5,6\% Akou. Adicionalmente, $44,4 \%$ criaron razas mixtas y $16,7 \%$ Holsteins. Se llevó a cabo un análisis de correspondencia múltiple para determinar la tipología de las fincas estudiadas. En base a las características estructurales (tamaño del hato, área de pastoreo, productividad diaria por vaca por día e infraestructura correspondiente) y funcionales (alimento, manejo de hato, método tecnológico) de las fincas, se identificaron tres tipos. Criadores tipo I (37\%) practicaron el sistema extensivo y los criadores tipo II $(18,5 \%)$ el sistema semi intensivo. Estuvieron presentes en la región de Adamawa y como medio reproductivo dieron preferencia a la copulación natural $(56 \%)$ e inseminación artificial $(100 \%)$ respectivamente. Los criadores tipo III (44,5\%) practicaron el sistema semi extensivo. Estuvieron presentes únicamente en las regiones Norte y Norte Lejano y prefirieron (98\%) la copulación natural como medio de reproducción. Los finqueros tipo II estaban localizados en la División de Vina (Adamawa) y ofrecieron los mejores potenciales para la práctica de la inseminación artificial. Podrían ser considerados como pilotos para un renacer del sector lechero en esta parte de Camerún.

Palabras clave: Bos indicus, inseminación artificial, tipología, cópula, producción lechera, Camerún 